Orientalia Christiana Cracoviensia 6 (2014), s. 9-26

DOI: http://dx.doi.org/10.15633/ochc.1103

Kamila Pawełczyk-Dura

pawelczyk.kamila@wp.pl

\title{
Islam i chrześcijaństwo w konserwatywnej myśli rosyjskiej XIX stulecia
}

\section{Konserwatyzm rosyjski i jego uwarunkowania}

Otwarcie konserwatyzmu na świat pradawnych wartości i przeświadczeń przeczyło ideałom oświeceniowym. Wiara we wszechmoc racjonalizmu nakazywała podporządkowanie się jednemu Rozumowi i rozwiązaniom uniwersalnym, wprowadzała monizm i unifikację, głoszone pod hasłami wolności, równości i braterstwa. Spierając się z tym, co narzucone i homogeniczne, konserwatyzm nie mógł mieć takiego charakteru. Broniąc tego, co wyjątkowe i niepowtarzalne, doświadczając złożoności i różnorodności zjawisk historycznych, nie wpisywał się (i nadal nie wpisuje się) w racjonalne schematy. Także definicyjne. Nigdy nie było jednego, określonego ściśle konserwatyzmu ani uproszczonej idei konserwatywnej: „w tym sensie należy raczej mówić o zespole pewnych cech, wartości, przeświadczeń i przesądów [...], a nie o spójnym systemie, który charakteryzowałby konserwatystów różnych czasów i w różnych krajach. Nie istnieje konserwatyzm modelowy i idealny, zawsze mamy do czynienia $\mathrm{z}$ konserwatywnym syndromem, który uzewnętrznia się odmiennie w poszczególnych przypadkach"'.

Niedefiniowalność pojęcia konserwatyzm przekłada się na niemożność rygorystycznego i jednoznacznego ujęcia tego zjawiska także na gruncie rosyjskim. Analiza koncepcji rosyjskich, daleka od negacji ich różnorodności i bogactwa, przywodzi jednakże ku następującej konstatacji: rozwinięte formy XIX-wiecznego konserwatyzmu rosyjskiego były, najprościej rzecz ujmując,

\footnotetext{
${ }^{1}$ M. Bohun, Piękno i przerażenie. Konstantin Leontjew i syndrom konserwatyzmu, [w:] Idee konserwatywne w Rosji, red. A. Raźny, Kraków 2010, s. 97-98.
} 
teoretycznie rozwiniętym uzasadnieniem Uwarowowskiej formuły prawosławie - samodzierżawie - narodowość ${ }^{2}$. Każda poważna rosyjska refleksja konserwatywna poruszała, uzasadniała, ewentualnie negowała poszczególne człony triady. „Była to tzw. «trójjedyna formuła»: prawosławie, samowładztwo i - po rosyjsku - narodnost', co może być thumaczone jako «ludowość» i jako narodowość. Dwa pierwsze określenia nie wymagają żadnych wyjaśnień i to są właśnie te precyzyjne «dwie trzecie». Inaczej przedstawia się sprawa z końcowym członem formuły, który zgodnie z zakresem znaczeniowym terminu rosyjskiego powinien być rozumiany podwójnie. Zarówno rodzime tendencje nacjonalistyczne, w takim czy innym stopniu przeciwstawiające się bliższym związkom z Zachodem, jak też pańszczyźniane i patriarchalne stosunki na wsi, rzekomo stanowiące odbicie harmonijnego stosunku między ludem i carem - oto jest «narodnost »"”.

Uwarowowska formuła zdominowała światopogląd konserwatywny myślicieli rosyjskich XIX wieku. Konserwatyzm czasów Mikołaja I, Aleksandra II i Aleksandra III w swoim zasadniczym zrębie ideowym nie odbiegał od modelu wypracowanego kilkadziesiąt lat wcześniej ${ }^{4}$. Do podstawowych komponentów trójjedynego wzoru dodawano jedynie kolejne elementy. Nadbudowa filozoficzna, społeczna i (lub) polityczna przekształcała myśl konserwatywną w swoistą ideologię, posługującą się teoretycznie dopracowanymi doktrynami i praktycznymi wywodami.

Konserwatywna idea rosyjska posiadała różnorodne punkty odniesienia, zależne od momentu historycznego, w którym się ujawniała. Ściślej rzecz ujmując, konserwatyzm rosyjski podsycany był wydarzeniami politycznymi i stanowił odruch obronny społeczeństwa czującego zagrożenie w tym, co obce, nierosyjskie. Konserwatywne pokłady świadomości narodowej uwydatniła wyprawa Napoleona Bonapartego na Rosję i kryzys 1812 roku, który przyczynił się do znacznej mobilizacji społeczeństwa rosyjskiego, do ogólnonarodowego solidaryzmu, wspólnej walki za ojczyznę. Podniósł hasło obrony wartości tradycyjnych i zahamował bezkrytyczne przyjmowanie w rosyjskim społeczeństwie wzorów zachodnich, głównie francuskich. Drugą połowię XIX stulecia zdominowała wojna krymska. Konflikt z Imperium Osmańskim, poza implikacjami geopolitycznymi związanymi z międzynarodowym konfliktem

${ }^{2} \mathrm{O}$ życiu, działalności i poglądach Sergiusza Uwarowa zob. М. М. Шевченко, С. С. Уваров в борьбе за новый курс внутренней политики России в 1826-1832 г2., [w:] П. А. Зайончковский (1904-1983). Статьи, публикации и воспоминания о нём, ред. Ю. С. Кукушкин, Москва 1998, s. 303-318; Л. М. Исамбаева, Общественно-политические взгляды С. С. Уварова в 1810-е годы, „Вестнник Московского университета” 1990 № 6, s. 24-35.

${ }^{3}$ L. Bazylow, Historia nowożytnej kultury rosyjskiej, Warszawa 1986, s. 282.

${ }^{4}$ Zob. szerzej: K. Pawełczyk-Dura, Kierunki i tendencje w XIX-wiecznej konserwatywnej myśli cerkiewnej w Rosji, „Prace Naukowe Akademii im. Jana Długosza w Częstochowie. Filozofia” 2012 nr 1, s. 183-196. 
militarnym, stał się katalizatorem przemian w państwie rosyjskim. Dotykały one zarówno sfery społeczno-gospodarczej (reforma uwłaszczeniowa), jak i mentalności społeczeństwa rosyjskiego. Poczucie zagrożenia ze strony Zachodu, świadomość słabości własnego państwa i zainteresowanie Wschodem - oto dominanty konserwatywnej myśli rosyjskiej tego okresu ${ }^{5}$.

Triada Zachód-Rosja-Wschód została, jeżeli nie po raz pierwszy sformułowana, to z całą pewnością szczegółowo przedstawiona przez Piotra Czaadajewa ${ }^{6}$. Uczynił on z niej podstawę swojego systemu historiozoficznego, rozwiniętego dalszą refleksją, jeszcze na kilka lat przed wybuchem wojny z Turcją. Rewolucyjność poglądów myśliciela połączona z oficjalnym sprzeciwem wobec dotychczasowego sposobu postrzegania Rosji, jej przeszłości, teraźniejszości i przyszłości, odbiegała zasadniczo od reakcyjnej atmosfery czasów Mikołajowskich. Nie mogła zdominować ówczesnego myślenia, postrzegania świata i własnego w nim miejsca. Głęboka treść jego refleksji nabrała nowej perspektywy dopiero w II połowie XIX wieku.

Jej oryginalność i odrębność, głoszoną przez Czaadajewa „inność” państwa i narodu rosyjskiego można rozpatrywać w różnych kontekstach i perspektywach. W niniejszej pracy odwołano się, obok ogólnego zarysu poglądów historiograficznych, do konserwatywnego spojrzenia na religie Zachodu, Rosji i Wschodu - na chrześcijaństwo i islam. Do analizy tego zagadnienia wybrano trzy postawy, trzy poglądy, ukazujące różnorodność myśli konserwatywnej i bogactwo jej interpretacji.

\section{Piotr Czaadajew (1794-1856) i Listy filozoficzne}

W 1836 roku w czasopiśmie „Teleskop” opublikowano pierwszy z cyklu ośmiu Listów filozoficznych Piotra Czaadajewa ${ }^{7}$. Pojawienie się traktatu stało się jednym z najbardziej zdumiewających, spektakularnych oraz istotnych wydarzeń w intelektualnej i politycznej historii Rosji. Jak pisał Aleksander Hercen, był to „wystrzał, który rozległ się wśród ciemnej nocy; czy coś tonęło i obwieszczało swoją zagładę, czy był to sygnał, wołanie o pomoc, zapowiedź świtu lub tego, że on nie nastanie - mniejsza o to, lecz trzeba się było obudzić"8.

${ }^{5}$ Zob. А. Ю. Минков, А. В. Репников, Консерватизм в России, [w:] Русский консерватизм середины XVIII - начала ХХ в. Энииклопедия, ред. В. В. Шелохаев, Москва 2010, s. 6-18.

${ }^{6}$ Zob. G. Przebinda, Od Czaadajewa do Bierdiajewa. Spór o Boga i człowieka w myśli rosyjskiej (1832-1922), Kraków 1998, s. 87-103; Idee w Rosji. Идеи в Poccuи. Ideas in Russia. Leksykon rosyjsko-polsko-angielski, red. A. de Lazari, t. 1, Warszawa 1999, s. 442-448; F. Copleston, Historia filozofii, przeł. B. Chwedeńczuk, t. 10, Warszawa 2009, s. 31-47.

${ }^{7}$ Zob. M. Chuda-Granat, Polska recepcja myśli Piotra Czaadajewa, [w:] Polskie badania filozofii rosyjskiej. Przewodnik po literaturze. Cz. 2, red. L. Kiejzik, J. Uglik, Warszawa 2012, s. 52.

${ }^{8}$ A. Walicki, Zarys myśl rosyjskiej. Od oświecenia do renesansu religijno-filozoficznego, Kraków 2005, s. 145. 
Listom przypisuje się charakter wręcz przełomowy. Uczyniły one z Czaaadajewa jedną z najatrakcyjniejszych postaci rosyjskich salonów literackich, wprowadziły nowe spojrzenie na dzieje Rosji i przyczyniły się bezpośrednio do jego upadku. $\mathrm{Na}$ osobisty wniosek samego cesarza uznano autora traktatu za obłąkanego i poddano przymusowej kontroli lekarskiej i policyjnej. Czasopismo „Teleskop” zamknięto, a redaktora Nadieżdina zesłano do Ust-Sysolska9 .

Przełomowość i innowacyjność Czaadajewskiego ujęcia polegały na całkowitym odrzuceniu oficjalnej ideologii czasów Mikołajowskich, głoszącej rozkwit Rosji i wzywającej do wypełnienia wśród pozostałych narodów najdonioślejszej misji „zbawienia” ludzkości. Rosja - twierdził - jest krajem pozbawionym tradycji, idei historycznej, moralnej i religijnej, a Rosjanie narodem, w którym próżno doszukiwać się wzniosłych przymiotów ducha i rozumu. Przypominają oni bardziej koczowników z ich tułaczym trybem życia i brakiem przywiązania do otaczającego ich środowiska niż społeczeństwo cywilizowane, rządzące się ideami prawa, sprawiedliwości, porządku ${ }^{10}$. W dziejach państwa i narodu autor Listów filozoficznych dostrzegał jedynie ordynarną ciemnotę i brutalne barbarzyństwo, co stanowiło osobliwy wyjątek w dziejach świata. „Żyjemy - podkreślał - wyłącznie teraźniejszością w jej najwęższym zasięgu, bez przeszłości i przyszłości, wśród martwego zastoju" "11. Taka Rosja była krajem istniejącym jedynie w wymiarze geograficznym, jako terytorium rozciągające od państwa niemieckiego aż po Chiny. Znajdowała się gdzieś pomiędzy Zachodem i Wschodem ${ }^{12}$.

Pesymistyczna i surowa wizja Rosji, istniejącej niejako poza czasem i przestrzenią kontrastuje z pozytywnym, wyidealizowanym obrazem Zachodu, który stanowić może dla Rosji - według Czaadajewa - zwierciadło samoświadomości ${ }^{13}$. Zachwyt nad „osobowością moralną” Europy niemalże nakazywał myślicielowi twierdzić, że „,im bardziej będziemy [Rosjanie - K. P.-D.] się starali z nią połączyć, tym lepiej będzie dla nas"14. Rosyjski partykularyzm narodowy i religijny, który wyrzucił Rosję poza obręb wielkiej wspólnoty europejskiej i pozbawił udziału

${ }^{9}$ Zob. T. Stefaniuk, Danilewski: panslawizm i wielość cywilizacji, Lublin 2006, s. 46-47.

${ }^{10}$ Zob. A. Walicki, Rosja, katolicyzm i sprawa polska, Warszawa 2002, s. 42; idem, Rosyjska filozofia i myśl społ.eczna od oświecenia do marksizmu, Warszawa 1973, s. 132-136.

${ }^{11}$ P. Czaadajew, Pierwszy list filozoficzny, [w:] idem, Listy, przeł. M. Leśniewska, L. Suchanek, Kraków 1992, s. 74.

${ }^{12}$ Zob. A. Walicki, Zarys myśl rosyjskiej. Od oświecenia do renesansu religijno-filozoficznego..., op. cit., s. 143; T. Stefaniuk, Danilewski: panslawizm i wielość cywilizacji, op. cit., s. 46.

${ }^{13}$ Poglądy Czaadajewa ewoluowały, o czym świadczyć może jego Apologia obłakanego, w której z niemałym entuzjazmem wypowiadał się o rosyjskim potencjale kulturotwórczym oraz o możliwości dominacji rosyjskiej na płaszczyźnie kultury. Zob. P. Czaadajew, Apologia obłakkanego, [w:] Wokót stowianofilstwa. Almanach myśli rosyjskiej, red. J. Dobieszewski. Warszawa 1998, s. 63-75.

${ }^{14}$ P. Czaadajew, Siódmy list filozoficzny, [w:] idem, Listy, przeł. M. Leśniewska, L. Suchanek, Kraków 1992, s. 172. 
w harmonijnym procesie rozwoju dziejowego, należało całkowicie odrzucić na rzecz typowo zachodniego społeczeństwa ponadindywidualnego, apologii tradycji i ciągłości historycznej oraz jedności religijnej ${ }^{15}$.

Autor Listów filozoficznych wierzył w przyszłość europejskiej cywilizacji chrześcijańskiej, jedynej, w której w pełni znalazły swe odbicie wartości materialne i duchowe całej ludzkości. Europejskie chrześcijaństwo, o którym pisze, wiąże jednak jedynie z katolicyzmem. Apologia Kościoła katolickiego, stanowiącego historyczną inkarnację królestwa Bożego na ziemi i realizującego światową misję ekumeniczną, zwracała się ku historiotwórczemu aktywizmowi rzymskiemu ${ }^{16}$. Jako siła społeczna i organizacyjna Kościół, kierowany przez papieża, stał się niegdyś symbolem powszechnego zjednoczenia ${ }^{17}$. $Z$ jedności, twierdził, najpierw zrezygnował Kościół prawosławny - poprzez schizmę odżegnujący się od życia prawdziwe duchowego i trwający w stanie empirycznej wegetacji. Następnie idei tej sprzeniewierzyła się reformacja, która „przywiodła świat do stanu rozdarcia i niejednorodności pogaństwa; przywróciła wielkie indywidualności moralne i izolację dusz i umysłów, usuniętą przez Zbawiciela"18.

Fascynacja chrześcijaństwem korespondowała z Czaadajewowską gloryfikacją „wywyższonego monoteizmu”. Z im większym przekonaniem wygłaszał tezy o konieczności rozpowszechniania po całym cywilizowanym świecie wiary $\mathrm{w}$ jednego Boga, z tym większym szacunkiem pisał o jednej z największych religii monoteistycznych Wschodu - islamie. W jednym ze swoich Listów filozoficznych podkreślał: „Jeżeli zastanowimy się nad dobrem, jakie wynikło dla ludzkości z jego [Mahometa - K. P.-D.] religii, przede wszystkim dlatego, że wraz z innymi, potężniejszymi przyczynami dopomogła ona w zniszczeniu politeizmu, a następnie dlatego, że rozpowszechniła na olbrzymiej połaci kuli ziemskiej, a nawet w strefach zdawałoby się niedostępnych dla ogólnego ruchu umysłowego ideę jedynego Boga i powszechnej wiary, i w ten sposób przygotowała niezliczone rzesze do ostatecznych zadań rodzaju ludzkiego. Jeżeli się zastanowimy nad tym wszystkim, będziemy zmuszeni przyznać, że mimo daniny, jaką ten wielki człowiek złożył zapewne swej epoce i miejscu

${ }^{15}$ Zob. A. Walicki, W kręgu konserwatywnej utopii. Struktura i przemiany rosyjskiego stowianofilstwa, Warszawa 2002, s. 73.

${ }^{16}$ Zob. idem, Rosja, katolicyzm i sprawa polska..., op. cit., s. 44; G. Przebinda, Od Czaadajewa do Bierdiajewa..., op. cit., s. 103.

${ }^{17}$ Zob. Idee w Rosji. Идеи в России. Ideas in Russia..., op. cit., s. 444.

${ }^{18}$ P. Czaadajew, Szósty list filozoficzny, [w:] idem, Listy, przeł. M. Leśniewska, L. Suchanek, Kraków 1992, s. 154. Zob. też: T. Obolevich, W trosce o Rosję i religię. Piotr Czaadajew, [w:] Navigare necesse Est. Księga Jubileuszowa dla Profesora Wojciecha Stomskiego z okazji 40. urodzin, Warszawa 2009, s. 495-500; G. Przebinda, Od Czaadajewa do Bierdiajewa..., op. cit., s. 94. 
swych narodzin, znacznie bardziej zasługuje na ludzkie hołdy niż cały ten tłum bezużytecznych mędrców"19.

Fenomen Mahometa i islamu są dla doszukującego się w świecie pewnego uniwersum Czaadajewa punktem oparcia, paradoksalnie, potwierdzającym tezę o demiurgicznej roli chrześcijaństwa i wpływie nauki Jezusa Chrystusa na kształtowanie się cywilizacji ogólnoludzkiej. Z prostej konstatacji „w Koranie prawie nie ma rozdziału, gdzie by nie było mowy o Chrystusie" ${ }^{20}$ wyciąga fundamentalny wniosek: wszędzie, gdzie wymawiane jest Jego imię, chrześcijaństwo wypełnia swoją misję powszechnej ewangelizacji, bo - jak pisał myśliciel - Chrystus ,działa na wszystkie umysły, mające jakąkolwiek styczność z Jego nauką"21. Czaadajew zaakcentował powszechność Chrystusowego objawienia, które dokonuje się w każdym czasie i w każdym miejscu. Jest to nieustanny proces, którego zrozumienie prowadzi do realizacji wielkiego dzieła odkupienia ludzkości i zgłębienia tajemnicy królestwa Bożego. Właśnie owa uniwersalność pozwała autorowi Listów filozoficznych spojrzeć na islam jako na jeden z najwspanialszych, najdoskonalszych przejawów ,„pewnego ogólnego prawa, sądzić o tym inaczej znaczyłoby negować powszechny wpływ chrześcijaństwa"22. Niedostrzeżenie w islamie jego chrześcijańskich korzeni jest równoznaczne dla myśliciela z brakiem jasnego, pełnego wyobrażenia o dokonującym się zbawieniu - jego głębokiej istocie i rzeczywistym sensie. Odrzucenie powszechności objawienia oznaczałoby wyłączenie z grona osób cieszących łaską odkupienia wielu osób uważających się chrześcijan i ,,sprowadzenia królestwa Chrystusowego do czegoś niezmiernie małego, a uniwersalnej natury chrześcijaństwa do żałosnej sekty"23.

Czaadajew, nawet krytykując islam, dostrzega zależność pomiędzy jej historycznym rozwojem i procesem kształtowania się społeczeństwa europejskiego. Ekspansywna natura arabska, dążąca do podbijania i poszerzania sfery swych wpływów, bezsprzecznie przyczyniła się do zjednoczenia świata chrześcijańskiego, „stapiając interesy cząstkowe narodów ze sprawą powszechnego zbawienia"24. Urozmaiciła go własnymi dokonaniami, osiągnięciami. Patrząc na szeroki krąg oddziaływania islamu na kraje i narody, które znalazły się pod przemożnym jego wpływem, nie można - w opinii myśliciela - nie dostrzegać bezpośredniego, oczywistego i dającego się uchwycić w ogólnej perspektywie działania tej nauki, z której on się wywodzi. W tym kontekście islam, który w opinii Czaadajewa „zajmuje pierwsze miejsce wśród zjawisk nie wywodzących się na pierwszy rzut

\footnotetext{
${ }^{19}$ P. Czaadajew, Siódmy list filozoficzny..., op. cit., s. 168.

${ }^{20}$ Ibidem.

${ }^{21}$ Ibidem.

${ }^{22}$ Ibidem.

${ }^{23}$ Ibidem, s. 169.

${ }^{24}$ Ibidem.
} 
oka z chrześcijaństwa, lecz niewątpliwie zeń pochodzących" ${ }^{25}$, paradoksalnie jawi się osobliwą formą chrześcijaństwa, dostosowującą się do okoliczności, do miejsca i czasu w celu szerzenia prawdy o Chrystusowym objawieniu na możliwie jak największym obszarze.

\section{Mikołaj Danilewski (1822-1885) i Rosja i Europa}

W 1869 roku na łamach miesięcznika „Zaria” ukazał się cykl artykułów, wydanych pod wspólnym tytułem Rosja i Europa. Pogląd na kulturalne i polityczne stosunki świata stowiańskiego z germańsko-romańskim, autorstwa Mikołaja Danilewskiego. Ich druk wznawiano kilkakrotnie, aż w końcu oryginalny tekst Danilewskiego został opublikowany w wersji książkowej, przynosząc autorowi uznanie w oczach współczesnych i przyznając jego dziełu poczesne miejsce $\mathrm{w}$ rosyjskiej historiozofii ${ }^{26}$.

Traktat Danilewskiego jest w swej istocie próbą odnalezienia miejsca Rosji na politycznej, cywilizacyjnej i kulturalnej mapie świata. Oryginalny wymiar nadało tym poszukiwaniom przekonanie o nieuniknionej konfrontacji z prężną, narzucającą niewymownie swą świadomość kulturą europejską, kulturą zachodnią. Apologia europocentryzmu dzielącego glob na dwie odrębne części - oświeconą Europę i nieokreśloną, niezdolną do odciśnięcia trwałego piętna w dziejach ludzkości „resztę świata” - została przez autora „kodeksu panslawizmu" gwałtownie zanegowana. Powyższy podział, jego zdaniem, miał charakter pewnej konwencji, tworzonej w oparciu o nielogiczne dane geograficzne i sztucznej z punktu widzenia nauk empirycznych ${ }^{27}$. Brak uzasadnienia w odgórnym grupowaniu krain geograficznych różniących się między sobą klimatem, krajobrazem, fauną i florą (na przykład Włochy i Hiszpania mają, w zamyśle myśliciela, więcej wspólnego z północnym wybrzeżem Afryki niż pozostałymi krajami Europy) w pewną całość, zwaną kontynentami, przywiodła Danilewskiego do stwierdzenia, że lepiej byłoby podzielić świat według klucza przynależności danego kraju do konkretnego typu kulturowo-historycznego. Zgodnie z tym schematem Europa przestawałaby być jednolitą dominantą na płaszczyźnie cywilizacyjnej, a stałaby się jedynie konglomeratem wielu państw i narodów. Zwalczyłoby to, z drugiej strony, pewne zafałszowanie, zgodnie z którym udziałem mniej cywilizowanej (barbarzyńskiej) ,reszty świata” jest jedynie zastój i stagnacja ${ }^{28}$.

\footnotetext{
${ }^{25}$ Ibidem.

${ }^{26}$ Zob. Niemarksistowska filozofia rosyjska. Antologia tekstów filozoficznych XIX i pierwszej połowy XX w. Cz. 1, red. L. Kiejzik, Łódź 2001, s. 154.

${ }^{27}$ Zob. Idee w Rosji. Идеи в Pоссии. Ideas in Russia..., op. cit., s. 142-143.

${ }^{28}$ Zob. T. Stefaniuk, Danilewski: panslawizm i wielość cywilizacji, op. cit., s. 63-65.
} 
Przekonanie autora Rosji i Europy o istnieniu nie jednej (europejskiej), lecz wielu cywilizacji, rozwijających się w mniejszym lub większym stopniu samoistnie, legło u postaw wyodrębnienia dziesięciu typów kulturowo-historycznych. Umieszczono je w porządku chronologicznym powstawania: egipski, chiński, syryjsko-babilono-fenicki (chaldejski lub starosemicki), indyjski, irański, żydowski, grecki, rzymski, nowosemicki (arabski) oraz germano-romański (europejski). Do grupy tej Danilewski dodał także dwa typy amerykańskie - meksykański i peruwiański, „które spotkała przedwczesna śmierć i które nie doczekały się swego dalszego rozwoju" ${ }^{29}$.

Wskazane wyżej typy nie są sobie współmierne, a zachodzące między nimi różnice rozwojowe dotyczą czterech pól aktywności kulturalnej: religijnej, kulturalnej (artystycznej i naukowo-technicznej), politycznej (państwowo-prawnej) oraz społeczno-ekonomicznej ${ }^{30}$. Najprostsze typy jednopierwiastkowe w toku rozwoju dziejowego osiągnęły pełnię jedynie w jednej z dziedzin (przykładowo typ hebrajski w sferze religii, a typ rzymski w zakresie politycznym). Typy wielopierwiastkowe mogą przejawiać się twórczo w wielu obszarach kultury, przy czym jedne z nich są całkowicie zamknięte, inne natomiast zdolne są asymilować materiał kulturalny stworzony przez typy współistniejące z nimi lub poprzedzające je czasowo. Typem zdolnym do szeroko zakrojonej twórczej asymilacji był dwupierwiastkowy (polityczno-kulturalny) typ europejski ${ }^{31}$.

Schemat rozwoju cywilizacyjnego przedstawił obrazowo Danilewski, porównując dzieje narodów i państwo do procesów zachodzących w świecie przyrody. Według niego typy kulturowo-historyczne rozwijają się w sposób, który najbardziej przypomina „te rośliny, u których okres wzrostu jest stosunkowo długi, zaś okres kwitnienia i owocowania - relatywnie krótki, i który raz na zawsze wyczerpuje ich siłę życiową”. Cywilizacje „rodzą się”, „dojrzewają”, a następnie „obumierają" i ,giną”, a ich dominacja w pewnym okresie jest zjawiskiem tymczasowym, efemerycznym. Nieuchronność procesu dziejowego nie pozostawia Danilewskiemu złudzeń - obecna, totalna hegemona Europy, a więc typu kulturowego, który apogeum sił twórczych osiągnął w wiekach XVI i XVII, dobiega końca. Jej miejsce zajmie nowa cywilizacja czteropierwiastkowa-słowiańska ${ }^{32}$.

Szczególna zdolność Słowian do rozumienia innych kultur i przyswajania sobie ich osiągnięć sprawiła, zdaniem myśliciela, że słowiański typ kulturowo-historyczny

${ }^{29}$ A. Walicki, Zarys myśl rosyjskiej. Od oświecenia do renesansu religijno-filozoficznego..., op. cit., s. 336; J. Diec, Cywilizacje bez okien. Teoria Mikołaja Danilewskiego i późniejsze koncepcje monadycznych formacji socjokulturowych, Kraków 2002, s. 31.

${ }^{30}$ Zob. Niemarksistowska filozofia rosyjska..., op. cit., s. 143.

${ }^{31}$ Zob. Idee w Rosji. Идеи в России. Ideas in Russia..., op. cit., s. 144-145.

${ }^{32}$ Zob. A. Walicki, Rosyjska filozofia i myśl społeczna od oświecenia do marksizmu..., op. cit., s. 433-434. 
będzie prawdopodobniej najbardziej zbliżony do ideału „wszechludzkości”33. Słowiańszczyzna uosabiała dla Danilewskiego ideał cywilizacyjny, na który nałożył obowiązek wyzwolenia, a następnie zjednoczenia wszystkich narodów słowiańskich. Misją dziejową narodu rosyjskiego była budowa silnego, prężnego państwa, które będzie w stanie podbić Konstantynopol i zjednoczyć Słowiańszczyznę. Wyzwolicielem i zjednoczycielem Danilewski nazywał oczywiście Rosję - jedyne państwo godne podniesienia tegoż obowiązku dziejowego: „Dla wyzwolenia z duchowej niewoli potrzebny jest ścisły sojusz z wszystkimi zniewolonymi, ujarzmionymi braćmi - konieczna jest walka, która zerwawszy wszystkie maski postawiłaby wrogów twarzą w twarz i zmusiłaby do odrzucenia kultu wobec znienawidzonych przeciwników. Dokonać tego może tylko surowa szkoła wydarzeń, tylko groźne doświadczenie historii. Owe celowe zdarzenia, od których przyjdzie (czy tego chcemy, czy nie) przyjąć zbawczą lekcję, już wschodzą na historycznym horyzoncie i nazywają się: Kwestia Wschodnia" ${ }^{34}$.

Problem wschodni wpisuje się w teorię typów kulturowo-historycznych, dla których walka i dominacja stanowi naturalny element rozwojowy. Współczesna Danilewskiemu konfrontacja typu europejskiego ze słowiańskim jest kontynuacją walki Grecji i Rzymu ${ }^{35}$. W tym kontekście dzieje powszechne nabierają perspektywy teleologicznej. Najwyraźniej uwidacznia ją ocena typu arabskiego i jego duchowej osnowy - islamu.

Zdaniem autora Rosji i Europy ogólna idea i dziejowa istota islamu zawiera się w przysłudze, którą wyznawcy islamu w pierwszych wiekach naszej ery okazali prawosławiu i Słowiańszczyźnie, „odgrodziwszy to pierwsze od naporu łacinnictwa, zbawiwszy to drugie od pochłonięcia przez europeizm, wówczas kiedy bezpośredni i naturalni obrońcy leżeli - jeden [Bizancjum] na łożu śmierci, a drugi [Rosja] w pieluszkach niemowlęctwa"36. Dokonało się to, jak twierdził myśliciel, bezwolnie i nieświadomie. Niemniej jednak tak radykalne odgrodzenie od Europy pozwoliło narodom słowiańskim zachować zalążek nowego życia, nowego typu cywilizacyjnego, który w przeciwnym razie zostałby wyparty i całkowicie przytłumiony potężnym wzrostem elementu germano-romańskiego. Dziejowa misja islamu, zdaniem Danilewskiego, została zakończona. Cywilizacja arabska - osiągnąwszy apogeum rozwoju - wyczerpała swoją siłę życiową i nie jest zdolna do dalszej, twórczej aktywności kulturowej, do udoskonalania materiału kulturowego. W tej sytuacji wojna Rosji z Turcją była nie tylko niemożliwa, ale także bezużyteczna i bezsensowna. $\mathrm{Z}$ założenia,

${ }^{33}$ Zob. Niemarksistowska filozofia rosyjska..., op. cit., s. 152-153; J. Diec, Cywilizacje bez okien..., op. cit., s. 93-94.

${ }^{34}$ A. Nowak, Polacy, Rosjanie i biesy. Studia i szkice historyczne z XIX i XX wieku, Kraków 1998, s. 55.

35 Tłumaczenie własne za: Н. Я. Данилевский, Россия и Европа, Москва 1991, s. 369.

${ }^{36}$ A. Nowak, Polacy, Rosjanie i biesy..., op. cit., s. 55. 
nie mogąc przynieść rezultatów w postaci bogatego materiału kulturowego, nie powinna angażować państwa rosyjskiego. Niezbędna i konieczna z punktu widzenia interesów Słowiańszczyzny jest, w ujęciu „kodeksu panslawizmu”, wojna z Europą, „wojna, która nie zakończy się oczywiście w ciągu jednego roku czy jednej kampanii, lecz zajmie cały okres historyczny" ${ }^{37}$.

Analiza religijnego fundamentu cywilizacji jest u Danilewskiego zdecydowanie mniej oryginalna niż ujęcie historiozoficzne. Typowo europocentryczna (chrystocentryczna) została zdominowana przekonaniem autora traktatu Rosja i Europa o wyższości chrześcijaństwa i niższości pozostałych religii, nieprzyczyniających się - jego zdaniem - do prężnego rozwoju kulturowego i historycznego narodów. Można rzec, że zepchnął on filozofię religii na margines swych zainteresowań, zwracając się ku niej jedynie celem uzasadnienia głoszonych tez o kulturowej odmienności Rosji i Europy. Stąd też wyraźny zwrot myśliciela w kierunku chrześcijaństwa ${ }^{38}$. Określenie relacji między wyznawaną wiarą a danym typem cywilizacyjnym zapożyczył bezpośrednio ze słowianofilskiej krytyki katolicyzmu i protestantyzmu oraz apologii prawosławia $^{39}$. Idealizacja wiary Kościołów Wschodu, wiary, bez której nie może być „rzeczywistej cywilizacji, to znaczy zbawienia w ziemskim sensie tego słowa”, była podyktowania, zdaniem autora „kodeksu panslawizmu”, wiarygodnością i czystością dogmatów, opartych na objawieniu ${ }^{40}$. Wyniesienie do rangi dogmatu nieomylności papieża (katolicyzm) oraz samodzielna interpretacja treści Pisma Świętego (protestantyzm) doprowadziło, twierdził, do negacji wartości i zasad „rzeczywistego", prawowiernego Kościoła. Jedynie prawosławie było zdolne do utrzymania autentyczności i wiarygodności Chrystusowego objawienia ${ }^{41}$. Stwierdzając, że wszystkie zachodnie nurty chrześcijaństwa są w istocie swej zwróconymi przeciwko rzeczywistemu Kościołowi (Kościołowi prawosławnemu) herezjami, Danilewski niewątpliwie zaprezentował się jako bezpośredni zwolennik i kontynuator refleksji Aleksego Chomiakowa ${ }^{42}$.

${ }^{37}$ Tłumaczenie własne za: Н. Я. Данилевский, Россия и Европа, op. cit., s. 393.

${ }^{38}$ Zob. J. Diec, Cywilizacje bez okien..., op. cit., s. 73-76.

${ }^{39}$ Zob. A. Nowak, Polacy, Rosjanie i biesy..., op. cit., s. 53.

${ }^{40}$ Cyt. za: T. Stefaniuk, Danilewski: panslawizm i wielość cywilizacji, op. cit., s. 113-114.

${ }^{41}$ Zob. M. А. Емельянов-Лукьянчиков, А. В. Репников, Данилевский, [w:] Русский консерватизм середины ХVIII - начала ХХ в. Энциклопедия, ор. cit., s. 145.

${ }^{42}$ Eklezjologia myśliciela słowianofilskiego stanowi próbę przedstawienia Ducha Bożego, objawiającego się w miłości i duchowej wolności. W ujęciu Chomiakowa jest on źródłem wspólnotowego życia Kościoła, daje poznanie i uświęca dusze, jednoczy swoich członków w miłości, objawia się jako światło i życie, stoi u początków nowego, wewnętrznego życia, przejawiającego się w braterstwie uczestników ekumeny. ,Jeżeli poznanie Boskich prawd dano wzajemnej miłości chrześcijan, to nie ma i nie może być innego stróża tych prawd poza miłością" - brzmiało przesłanie Chomiakowa. Miłość była dla niego wolnością, a „bez wolności nie możemy mówić o miłości”. Cerkiew - mistyczne ciało Chrystusa to żywy organizm, jedność miłości, niewypowiedziana wolność, prawda i świętość, przeciwieństwo narzuconego jednostkową wolą autorytetu. Jedność 
Islam, twierdził Danielewski, pojawił się sześć wieków po tym, jak absolutna prawda zbawienia i wyzwolenia ludzkości została już ogłoszona światu przez Jezusa Chrystusa. Z tego powodu myśliciel odmawiał islamowi miana religii. Widzi w nim jedynie pewne zjawisko - niedoskonałe w swej istocie, pozbawione misji zbawczej, niewnoszące własnego wkładu w działalność kulturalną ludzkości, a niekiedy nawet niebezpieczne dla chrześcijaństwa: „Głównym obszarem życia i działania islamu były nie kraje zaludnione przez pogan, dla ordynarności których nauka Chrystusowa była zbyt podniosła, a wprost przeciwnie - kraje, dawno już oświecone przez tę naukę, przyjmujące ją i przynoszące owoce, w żaden sposób nie mniej obfite i nie mniej wspaniałe niż kraje leżące pod surowszym niebem albo w bardziej umiarkowanym klimacie"43.

Nauka Mahometa, twierdził, nie była w stanie przygotować odpowiedniego gruntu pod przyjęcie chrześcijaństwa w jego pełnej formie. Cała cywilizacja arabska, nie wykazując żadnych skłonności do twórczego rozwoju, zastygając w swej religijności, wydatnie opierała się wpływowi chrześcijaństwa. Stanowiła zatem, według Danilewskiego, przeszkodę w jego rozszerzaniu: „Z religijnego punktu widzenia nauka arabskiego proroka jest widocznym krokiem w tył - niewytłumaczalną anomalią historyczną" "44. Islam, budując swoją potęgę, podbijał pozostałe narody. Nie tylko pogańskie, dla których - zdaniem autora „kodeksu panslawizmu” - Chrystusowe objawienie było zbyt trudne do zrozumienia i przyjęcia, ale także te oświecone przez tę naukę, przynosząc im niepowetowaną szkodę. Cywilizacja arabska, szczycąc się swoimi osiągnięciami, nie dostrzegała krzywdy, którą wyrządziła ludzkości. Także w sferze kulturowej. Pomniejszanie wkładu islamu w dziedzictwo rozwiniętych cywilizacji ilustrował kilkoma przykładami. W jednym z nich dowodził, że dzieła greckich filozofów i myślicieli, znane w okresie późniejszym w Europie z przekładów z języka arabskiego, zachowałyby się w pełniejszej, nie tak zniekształconej wersji, gdyby kraje podbite przez Arabów pozostały częścią państwa greckiego. W innym podkreślał, że znane powszechnie i znajdujące swe zastosowanie wynalazki chińskie z całą pewnością dotarłyby do Europy dzięki chrześcijanom, gdyby ci nie zostali odgrodzeni od Wschodu podbojami i ekspansją arabską. Danilewski konstatował: „Bez względu na to, jak byśmy

wspólnoty wiernych wypływa z ich wolności, gdyż miłość nie jest obowiązkiem, a jedynie darem zabezpieczającym poznanie prawdy. W tej perspektywie teologiczno-filozoficznej nieomylność przynależy całemu Kościołowi jako Ciału Chrystusa. Myśl ta koresponduje ze słynną Encyklika patriarchów wschodnich z 1848 roku, stanowiącą odpowiedź na encyklikę papieża Piusa IX In suprema Petri Apostolica Sede, o której Chomiakow pisał: „Z otchłani poniżenia, w jakiej islam trzyma wschodnich chrześcijan, rozległ się głos, żeby powiedzieć światu, że poznanie prawdy dane jest wzajemnej miłości chrześcijan”. Zob. szerzej: T. Stefaniuk, Danilewski: panslawizm $i$ wielość cywilizacji, op. cit., s. 55-59.

${ }^{43}$ Tłumaczenie własne za: Н. Я. Данилевский, Россия и Европа, оp. cit., s. 377-378.

${ }^{44}$ Tłumaczenie własne za: ibidem, s. 378. 
nie szukali, nie znajdziemy usprawiedliwienia dla islamu w wewnętrznych, kulturalnych osiągnięciach tego ruchu. $\mathrm{Z}$ tego punktu widzenia on zawsze będzie stanowić zagadkowy, niezrozumiały krok historii”45.

\section{Konstanty Leontjew (1831-1891) \\ i Bizantynizm i Stowiańszczyzna}

Bizantynizm i Słowiańszczyzna, traktat wydany w 1875 roku, jest dziełem równie barwnym i indywidualnym jak jego autor - Konstanty Leontjew. Rosyjski pisarz, myśliciel, z wykształcenia lekarz, przez wiele lat pełniący służbę dyplomatyczną $\mathrm{w}$ różnych miastach imperium tureckiego, następnie - $\mathrm{z}$ racji kontrowersyjnych poglądów politycznych - parający się pracą redaktora i cenzora, a pod koniec życia mnich prawosławny z całą pewnością nie był postacią sztampową ${ }^{46}$. Osobowość i szokujące dla współczesnych poglądy i zapatrywania zamknęły przed nim salony elit rosyjskich i skazały na obojętność ze strony ówczesnej inteligencji. Leontjewa doceniono dopiero po śmierci. „Nawet ci - pisał Michał Bohun - którzy nie podzielali jego przekonań, ujrzeli w nim jeżeli nie największego, to z pewnością najciekawszego myśliciela konserwatywnego dziewiętnastowiecznej Rosji”"47.

Bizantynizm i Słowiańszczyzna to $\mathrm{w}$ istocie głęboka analiza trójjedynego procesu, odzwierciedlającego logikę organicznego rozwoju, rozszerzonego na wszystkie niemalże dziedziny. Każdy rozwój - biologiczny, społeczny, polityczny i inny - jest zjawiskiem schematycznym, gdyż mieści się w trzech podstawowych stadiach. Pierwsze z nich, w refleksji myśliciela, stanowi pierwotna jednorodność elementów składowych i prostota całości. Na kolejnym, drugim poziomie, pojawia się złożoność i indywidualizacja poszczególnych części i całości, które muszą być coraz silnej spajane przez jedność formy. Leontjew rozumiał ją jako despotyzm wewnętrzny, który powstrzymuje materię przed rozpadem i utrzymuje jej substancjonalny byt. Punktem kulminacyjnym tego stadium jest „kwitnąca złożoność”, kiedy wewnętrzna różnorodność jest największa, a jedność najbardziej despotyczna. Od tego momentu rozpoczyna się stadium trzecie - rozkład, w którym dochodzi do ponownego ujednorodniania, spajania elementów składowych i uproszczenia całości. Zapowiada ono zbliżającą się śmierć organizmu ${ }^{48}$.

${ }^{45}$ Tłumaczenie własne za: ibidem, s. 379.

${ }^{46}$ Zob. Idee w Rosji. Идеи в Pоссии. Ideas in Russia..., op. cit., s. 222.

${ }^{47}$ M. Bohun, Piękno i przerażenie..., op. cit., s. 97-98. O polskich badaniach filozofii Leontjewa zob. też: L. Augustyn, Konserwatywny Rosjanin i przyszłość Rosji. Filozofia Konstantego Leontjewa widziana z polskiej perspektywy, [w:] Polskie badania filozofii rosyjskiej. Przewodnik po literaturze. Cz. 1, red. L. Kiejzik, J. Uglik, Warszawa 2009, s. 131-149.

${ }^{48}$ Zob. K. Leontjew, Bizantynizm i Stowiańszczyzna (tłum. M. Bohun), [w:] Wokół Leontjewa i Bierdiajewa. Almanach myśli rosyjskiej, red. J. Dobieszewski, Warszawa 2001, s. 146-151; 
$\mathrm{Na}$ tym ostatnim etapie rozwojowym, etapie rozkładu, znajduje się - w przekonaniu myśliciela - społeczeństwo europejskie, które niweluje naturalną nierówność społeczną, wypiera scalające organizm państwowy siły despotyczne i wprowadza to, co pospolite, powszechne, po prostu przeciętne. Wartości, kształtujące XIX-wieczne społeczeństwo europejskie uznał za destrukcyjne nie tylko dla porządku państwowego, ale także dla człowieka. W tak zwyrodniałej rzeczywistości, twierdził, pojawia się nowy typ ludzki, przyspieszający swym nędznym, miernym życiem nieuchronny i bliski upadek. Leontjewowską receptą na zatrzymanie rozkładu jest bizantynizm. Bizantynizm to „zespół przymusowych zasad życia społecznego, na których wspiera się nie tylko rosyjska, ale i powszechna reakcja”, to „zasada światowa, a nie narodowa”, a w odniesieniu do państwa rosyjskiego to „despotyczna forma Rosji, czyli ideał struktury, organizacji, hierarchii społecznej i bezwzględnej, prawem stanowionej nierówności; ideał, który ucieleśniany jest w życiu historycznym przez dwa filary rosyjskości: cara i Kościół”49.

W pracy Bizantynizm i Słowiańszczyzna podkreślał, że państwo powinno być groźne, niekiedy brutalne i niemiłosierne, ponieważ społeczeństwo zawsze i wszędzie realizuje sprzeczne ze sobą cele. Powstrzymać chaos mógł jedynie, jego zdaniem, aparat państwa. Monarcha i jego urzędnicy, podobnie jak Kościół prawosławny, wypełniali swoje dziejowe posłannictwo. Cerkiew rosyjska na przestrzeni dziejów, jak wykazywał konserwatysta, zmuszała ludzi do okiełznania swojej indywidualności w imię dobra najwyższego. Zbawieniem rodzaju ludzkiego w sensie religijnym zajmowała się Cerkiew, a w sensie społecznym - państwo $^{50}$. Te dwie potężne, dyscyplinujące siły opierały swój autorytet na strachu. Państwo, twierdził, ma do dyspozycji legalny aparat przemocy, mogący utrzymać ład społeczny i zniwelować destrukcyjne namiętności ludzi ${ }^{51}$. Kościół natomiast opierał swój autorytet na bardziej subtelnym strachu, wypływającym z „bojaźni Pańskiej”, trwogi przed śmiercią i wiecznym potępieniem. Religia,

J. Diec, Cywilizacje bez okien..., op. cit., s. 112; A. Walicki, Rosja, katolicyzm i sprawa polska..., s. 153; Idee w Rosji. Идеи в России. Ideas in Russia..., op. cit., s. 222-223; A. Korolkow, Proroctwa Konstantego Leontjewa, thum. S. Chojnacka, Torun 1994, s. 17-47.

${ }^{49}$ M. Bohun, Piękno i przerażenie..., op. cit., s. 108; M. Broda, Historia a eschatologia. Studia nad myśla Konstantego Leontjewa i ,zagadka Rosji”, Łódź 2001, s. 188-207. Zob. też: M. Bohun, ,, Socjalizm albo unicestwienie”. O pewnej konserwatywnej wizji modernizacji Rosji, [w:] Filozofia rosyjska wobec problemów modernizacyjnych, red. W. Rydzewski, M. Bohun, Kraków 1999, s. 261-266; M. Broda, Najtrudniejsze z rosyjskich wyzwań? Zagadka Leontjewa i Rosja, Łódź 1995, s. 49-53.

${ }^{50}$ Zob. M. Bohun, Piękno i przerażenie..., op. cit., s. 109; J. Diec, Cywilizacje bez okien..., op. cit., s. 115-116.

${ }^{51}$ Zob. M. Bohun, Kontrrewolucja i pesymizm. Filozofia społeczna Konstantina Leontjewa, Kraków 2000, s. 234-235. 
kierując myśli człowieka ku sprawom ostatecznym, sprzyjała porządkowi społecznemu, a przez to utrwalała zastany ład $^{52}$.

Uwagę Leontjewa przyciągały Kościoły i wyznania, występujące przeciwko zwodniczej nowoczesności i pielęgnujące własne, bogate tradycje. Religia interesuje go głównie jako sprawcza siła historyczna i kulturowo-polityczna. Pomijając wymiar mistyczny i doktrynalny innych religii, głównie katolicyzmu $\mathrm{i}$ islamu, mógł odnosić się do nich z szacunkiem, a nawet z pewnym zachwytem. Powszechnie krytykowany w Rosji katolicyzm był dla Leontjewa zjawiskiem na wskroś pozytywnym - budującym i kształtującym oblicze świata zachodniego. Był źródłem rozkwitu kultury europejskiej. Kościół rzymski pociągał go swoją potęgą, aktywnością, uniwersalizmem przejawiającym się w podporządkowaniu ideałów partykularnych zasadom wyższym, idealnym ${ }^{53}$. Odpychało go zreformowane chrześcijaństwo, wyrosłe z ducha sprzeciwu i negacji wobec katolicyzmu oraz postulujące indywidualizm i wolność. Podziwiał Kościół hierarchiczny i całkowicie scentralizowany, poddany absolutnej niemalże władzy papieży. „W historii katolicyzmu - pisał - co krok to twórczość, samoistność, niezależność, siła" ${ }^{54}$. Właśnie w despotycznej formie organizacji życia kościelnego i silnej, absolutnej władzy papieża dostrzegał możliwość umocnienia prawosławia. Wyzwolony i niezależny Kościół prawosławny mógłby być zdolny do oporu wobec państwa, które zbyt łatwo poddaje się destrukcyjnemu ,procesowi liberalno-egalitarnemu" - europejskiemu rozkładowi i upadkowi ${ }^{55}$.

Leontjewowska fascynacja Turcją i Bliskim Wschodem, ugruntowana wieloletnią służbą konsularną w państwach Imperium Osmańskiego - na Krecie, w Salonikach i Konstantynopolu, miała swoje odzwierciedlenie w stosunku autora traktatu Bizantynizm i Słowiańszczyzna do islamu ${ }^{56}$. Nieukrywany zachwyt, jaki wyrażał wobec religii Mahometa, całkowicie zdominował jego wizję chrześcijaństwa. Wpływ ten jest na tyle wyczuwalny, że niektórzy badacze i komentatorzy idei Leontjewa posunęli się nawet do stwierdzenia, że ,jego religijność bardziej przypominała islam niż prawosławie, z wierności któremu był tak dumny" ${ }^{57}$. Analogia między chrześcijaństwem a islamem, która skłania ku powyższemu stwierdzeniu, zawiera się w dwóch elementach światopoglądu

${ }^{52}$ Zob. ibidem, s. 178; M. Broda, Historia a eschatologia. Studia nad myśla Konstantego Leontjewa $i$,zagadka Rosji”..., op. cit., s. 155, 174; idem, Najtrudniejsze z rosyjskich wyzwań? ..., op. cit., s. 58-61; A. Korolkow, op. cit., s. 81-89.

${ }^{53}$ Zob. M. Lechowska, Bóg czy bożek? Myśl religijna Konstantego Leontjewa, [w:] Idee konserwatywne w Rosji, red. A. Raźny, Kraków 2010, s. 121-122.

${ }^{54}$ M. Bohun, Kontrrewolucja i pesymizm..., op. cit., s. 183.

${ }^{55}$ Zob. M. Broda, Historia a eschatologia ..., op. cit., s. 167-169.

${ }^{56}$ Zob. A. В. Репников, М. А. Емельянов-Лукьянчиков, К. Н. Леонтьев, [w:] Русский консерватизм середины ХVIII - начала ХХ в. Энциклопедия, оp. cit., s. 269-270.

${ }^{57}$ M. Bohun, Kontrrewolucja i pesymizm. Filozofia spoleczna Konstantina Leontjewa..., op. cit., s. 187. 
myśliciela: z jednej strony w jego koncepcji Kościoła jako organizacji wypełniającej ważną społecznie misję , z drugiej - w jego wyobrażeniu Boga.Jak już wyżej powiedziano, marzeniem Leontjewa był Kościół scentralizowany, hierarchiczny, aktywny i odważny w swym działaniu historycznym, twórczy kulturowo i politycznie. Na Zachodzie ideał ten ucieleśniały katolicyzm i papiestwo, na Wschodzie zaś islam i kalifat. Jako organizacja religijno-polityczna kalifat całkowicie skupił się na budowaniu silnej, niezależnej wspólnoty, a w wymiarze praktycznym - urzeczywistniał doktrynę ,szerzenia wiary” i dążył do panowania nad innymi narodami. W swej ekspansywności, systemie absolutystycznej organizacji i polityczno-społecznej działalności teokratyzm muzułmański był bardziej agresywny niż katolicyzm. Miał większe możliwości dyscyplinujące, a zarazem jednoczące. Z przedstawienia formy zewnętrznej kalifatu wyłania się częściowo także obraz Boga, którego reprezentuje. Jest On daleki i transcendentny, pełen surowości i potępienia wobec ludzkich grzechów. To karzący sędzia i srogi Ojciec. W Leontjewowskiej wizji Boga brakuje atrybutów boskich, charakterystycznych dla „różowego chrześcijaństwa", które potępiał z taką zaciętością ${ }^{58}$. Brakuje nade wszystko - druga analogia z islamem - centralnej postaci Chrystusa ${ }^{59}$. Zbawiciela kochającego i przebaczającego, oddającego swe życie za grzechy ludzkości. Człowiek, jego zdaniem, nie powinien kierować się wyabstrahowaną miłością, ale bojaźnią i wypływającą zeń pokorą. Strach, będący źródłem posłuszeństwa i dyscypliny, stanowi o istocie prawdziwej wiary ${ }^{60}$.

Wreszcie zaś: ,Z jeszcze innego powodu muzułmanizm wzbudzał sympatię rosyjskiego myśliciela. Dostrzegał w nim religię, która przy swojej surowości i dyscyplinującym charakterze, jednocześnie dopuszczała wykwintne i bogate formy życia. Fascynowało go orientalne połączenie okrucieństwa i finezji, strachu przed Bogiem z dążeniem do doczesnych rozkoszy, pełne oddanie się wierze i zarazem umiejętność zachwycania się „poezją życia”. Była to religia, która jednoczyła w sobie sprzeczności ziemskiej rzeczywistości: surową etykę i estetyczny hedonizm, jednakowo ceniąc rozkosz i religijne samopoświęcenie" ${ }^{\prime 1}$.

\footnotetext{
${ }^{58}$ O stosunku Leontjewa do „różowego chrześcijaństwa” zob. A. Walicki, Rosja, katolicyzm i sprawa polska ..., op. cit., s. 154-155; M. Bohun, Konstantin Leontjew i mity świadomości utopijnej, [w:] Wokół Leontjewa i Bierdiajewa..., op. cit., s. 42.

${ }^{59} \mathrm{Zob}$. Н. А. Бердяев, Константин Леонтьев: Очерк из истории русской религиозной мысли, [w:] К. Н. Леонтьев: pro et contra. Личность и творчество К. Леонтьева в оченке рус. мыслителей и исследователей после 1917 г., подгот. А. П. Козырев, А. А. Корольков, Санкт-Петербург 1995, s. 176.

${ }^{60}$ Zob. M. Broda, Historia a eschatologia..., op. cit., s. 155.

${ }^{61}$ M. Bohun, Kontrrewolucja i pesymizm..., op. cit., s. 188.
} 


\section{Wnioski}

Islam w XIX-wiecznej rosyjskiej myśli religijno-filozoficznej był jednym z elementów historiozofii ukazującej w perspektywie kulturowo-historycznej dzieje własnego narodu i państwa oraz pokazującej przeszłość, teraźniejszość i przyszłość rodzimego Kościoła prawosławnego. Sprzyjała ona wykrystalizowaniu się wizji szczególnej drogi rozwoju Rosji, postrzegania jej jako ogniwa łączącego Wschód i Zachód. Idea ta, przedstawiona przez Czaadajewa, znajduje swoich kontynuatorów w osobach Danilewskiego i Leontjewa. Ostatecznie zaś, w wieku XX, wśród teoretyków euroazjatyzmu. Występuje także w muzułmańskiej myśli społecznej, w szczególności w pracach İsmaila Gasprinsliego.

Teoretyczny model konserwatywny, postulujący nadanie Rosji odpowiedniego, godnego jej osiągnięć i możliwości miejsca w cywilizowanym świecie, nie mógł powstać bez uwzględnienia skomplikowanych stosunków zachodzących w rosyjskiej historii między chrześcijaństwem i islamem oraz wyrosłych na ich gruncie tradycji. Konserwatywne ujęcie historiozoficzne dalekie jest od jednorodnej, schematycznej oceny islamu. Dostrzegano w nim zjawisko pozytywne - budujące, o dużym potencjale oraz negatywne - destruktywne, niezdolne do dalszego rozwoju. $Z$ jednej strony budzące zainteresowanie, a nawet niekłamany zachwyt. Z drugiej - ignorowane, niekiedy deprecjonowane. W każdym przypadku konserwatyści rosyjscy, świadomie lub nieświadomie, przyczynili się w znacznym stopniu do przypominania o roli islamu w procesie kształtowania się świadomości narodowej. Postawa ta korespondowała z samym faktem istnienia religii Mahometa jako zjawiska historycznego i socjokulturowego.

\section{Abstrakt}

W rosyjskiej myśli konserwatywnej XIX stulecia islam był elementem filozofii historii, która ujmowała historię narodu i państwa w perspektywie historycznej i kulturowej. Ponadto prezentowała przeszłość, teraźniejszość oraz przyszłość Rosyjskiej Cerkwi Prawosławnej. Konserwatyzm stworzył przy tym wizję szczególnego rozwoju Rosji jako ogniwa łączącego Wschód z Zachodem. Żądanie zapewnienia Rosji wyjątkowej pozycji w cywilizowanym świecie, odpowiadającej jej osiągnięciom i możliwościom nie mogło być zrealizowane bez uwzględnienia złożonych relacji między chrześcijaństwem a islamem w historii Rosji i bez uwzględnienia tradycji, które rozwijały się na jej terytorium. Konserwatywna myśl historiozoficzna odnosząca się do islamu nie była bynajmniej jednorodna, co potwierdzają poglądy czołowych przedstawicieli - Piotra Czaadajewa, Mikołaja Danilewskiego i Konstantina Leontjewa.

\section{Słowa kluczowe}

Islam; chrześcijaństwo; rosyjski konserwatyzm; XIX wiek; Piotr Czaadajew; Mikołaj Danilewski; Konstantin Leontjew 


\section{Abstract}

\section{Islam and Christianity in the conservative Russian thought of the $19^{\text {th }}$ century}

In the conservative Russian religious-philosophical idea of the $19^{\text {th }}$ century, Islam was an element of the philosophy of history which demonstrated the history of its own nation and state in a cultural and historical perspective. What is more, it showed the past, the present and the future of the Russian Orthodox Church. Conservatism created a vision of a particular way of development of Russia as a nexus of the East and the West. The postulate to provide Russia with a suitable place in the civilized world, adequately to its achievements and capabilities, could not be accomplished without considering the complex relationships between Christianity and Islam in Russian history and without the traditions which had grown on them. The conservative historiosophical idea pertaining to Islam was not homogeneous, which confirmed the views of the leading ideologists of the movement - Petr Chaadayev, Nikolay Danilewsky and Konstantin Leontyev.

\section{Keywords}

Islam; Christianity; Russian conservatism; $19^{\text {th }}$ century; Petr Chaadeyev; Niklay Danilevsky; Konstantin Leontyev

\section{Bibliografia}

Augustyn L., Konserwatywny Rosjanin i przyszłość Rosji. Filozofia Konstantego Leontjewa widziana z polskiej perspektywy, [w:] Polskie badania filozofii rosyjskiej. Przewodnik po literaturze. Cz. 1, red. L. Kiejzik, J. Uglik, Warszawa 2009, s. 131-149.

Bazylow L., Historia nowożytnej kultury rosyjskiej, Warszawa 1986.

Бердяев Н. А., Константин Леонтьев: Очерк из истории русской религиозной мысли, [w:] K. Н. Леонтьев: pro et contra. Личность и творчество К. Леонтьева в оченке рус. мыслителей и исследователей после 1917 г., подгот. А. П. Козырев, А. А. Корольков, Санкт-Петербург 1995.

Bohun M., ,Socjalizm albo unicestwienie”. O pewnej konserwatywnej wizji modernizacji Rosji, [w:] Filozofia rosyjska wobec problemów modernizacyjnych, red. W. Rydzewski, M. Bohun, Kraków 1999, s. 261-266.

Bohun M., Piękno i przerażenie. Konstantin Leontjew i syndrom konserwatyzmu, [w:] Idee konserwatywne w Rosji, red. A. Raźny, Kraków 2010, s. 97-115.

Broda M., Najtrudniejsze z rosyjskich wyzwań? Zagadka Leontjewa i Rosja, Łódź 1995.

Broda M., Historia a eschatologia. Studia nad myśla Konstantego Leontjewa i ,zagadka Rosji”, Łódź 2001.

Chuda-Granat M., Polska recepcja myśli Piotra Czaadajewa, [w:] Polskie badania filozofii rosyjskiej. Przewodnik po literaturze. Cz. 2, red. L. Kiejzik, J. Uglik, Warszawa 2012.

Copleston F., Historia filozofii, przeł. B. Chwedeńczuk, t. 10, Warszawa 2009.

Czaadajew P., Pierwszy list filozoficzny, [w:] P. Czaadajew, Listy, przeł. M. Leśniewska, L. Suchanek, Kraków 1992.

Czaadajew P., Szósty list filozoficzny, [w:] P. Czaadajew, Listy, przeł. M. Leśniewska, L. Suchanek, Kraków 1992. 
Czaadajew P., Siódmy list filozoficzny, [w:] P. Czaadajew, Listy, przeł. M. Leśniewska, L. Suchanek, Kraków 1992.

Czaadajew P., Apologia obłąkanego, [w:] Wokót słowianofilstwa. Almanach myśli rosyjskiej, red. J. Dobieszewski, Warszawa 1998, s. 63-75.

Данилевский Н. Я., Россия и Европа, Москва 1991.

Diec J., Cywilizacje bez okien. Teoria Mikołaja Danilewskiego i późniejsze koncepcje monadycznych formacji socjokulturowych, Kraków 2002.

Idee w Rosji. Идеи в России. Ideas in Russia. Leksykon rosyjsko-polsko-angielski, red. A. de Lazari, t. 1, Warszawa 1999.

Исамбаева Л. М., Общественно-политические взгляды С. С. Уварова в 1810-е годы, „Вестнник Московского университета” 1990 № 6, s. 24-35.

Емельянов-Лукьянчиков М. А., Репников А. В., Данилевский, [w:] Русский консерватизм середины XVIII - начала XX в. Энцииклопедия, ред. В. В. Шелохаев, Москва 2010.

Korolkow A., Proroctwa Konstantego Leontjewa, thum. S. Chojnacka, Torun 1994.

Lechowska M., Bóg czy bożek? Myśl religijna Konstantego Leontjewa, [w:] Idee konserwatywne w Rosji, red. A. Raźny, Kraków 2010.

Leontjew K., Bizantynizm i Słowiańszczyzna (tłum. M. Bohun), [w:] Wokót Leontjewa i Bierdiajewa. Almanach myśli rosyjskiej, red. J. Dobieszewski, Warszawa 2001, s. 146-151.

Минков А. Ю., Репников А. В., Консерватизм в России, [w:] Русский консерватизм середины XVIII - начала ХХ в. Энчиклопедия, ред. В. В. Шелохаев, Москва 2010, s. 6-18.

Niemarksistowska filozofia rosyjska. Antologia tekstów filozoficznych XIX i pierwszej połowy $X X$ w. Cz. 1, red. L. Kiejzik, Łódź 2001.

Nowak A., Polacy, Rosjanie i biesy. Studia i szkice historyczne z XIXi XX wieku, Kraków 1998.

Obolevich T., W trosce o Rosję i religię. Piotr Czaadajew, [w:] Navigare necesse Est. Księga Jubileuszowa dla Profesora Wojciecha Stomskiego z okazji 40. urodzin, Warszawa 2009, s. $495-500$.

Pawełczyk-Dura K., Kierunki i tendencje w XIX-wiecznej konserwatywnej myśli cerkiewnej w Rosji, „Prace Naukowe Akademii im. Jana Długosza w Częstochowie. Filozofia” 2012 nr 1, s. 183-196.

Przebinda G., Od Czaadajewa do Bierdiajewa. Spór o Boga i człowieka w myśli rosyjskiej (1832-1922), Kraków 1998.

Репников А. В., Емельянов-Лукьянчиков М. А., К. Н. Леонтьев, [w:] Русский консерватизм середины XVIII-начала XX в. Энциклопедия, ред. В. В. Шелохаев, Москва 2010, s. 269-270.

Stefaniuk T., Danilewski: panslawizm i wielość cywilizacji, Lublin 2006.

Шевченко М. М., С. С. Уваров в борьбе за новый курс внутренней политики России в 1826-1832 г2., [w:] П. А. Зайончковский (1904-1983). Статьи, публикаџии и воспоминания о нём, ред. Ю. С. Кукушкин, Москва 1998, s. 303-318.

Walicki A., Rosyjska filozofia i myśl społeczna od oświecenia do marksizmu, Warszawa 1973.

Walicki A., Rosja, katolicyzm i sprawa polska, Warszawa 2002.

Walicki A., W kręgu konserwatywnej utopii. Struktura i przemiany rosyjskiego stowianofilstwa, Warszawa 2002.

Walicki A., Zarys myśl rosyjskiej. Od oświecenia do renesansu religijno-filozoficznego, Kraków 2005. 